\title{
Broadband Network Fiber to the Home (FttH) Design for Improving Performance of Information and Telecommunication Network in Riau University
}

\author{
Ery Safrianti \\ Department of Electrical Engineering \\ Faculty of Engineering \\ Universitas Riau, Indonesia
}

\author{
'Linna Oktaviana Sari \\ Department of Electrical Engineering \\ Faculty of Engineering \\ Universitas Riau, Indonesia
}

\author{
Dwi Putra Retdha Yuhana \\ Department of Electrical Engineering \\ Faculty of Engineering \\ Universitas Riau, Indonesia
}

*corresponding author: Ery Safrianti, esafrianti@eng.unri.ac.id

\begin{abstract}
Increased demand for information and telecommunications at the University of Riau demanding reliable carrier network availability. Copper cable network that now exists less support for multimedia network performance. Therefore, it is necessary to design a new access networks. One alternative is to implement fiber optic technology Fiber to the Home (FttH). This research design a FttH network for information access needs on the campus site, located in Panam, Pekanbaru. The results show the needs of Optical Network Terminal (ONT) as many as 209 units and 34 units of Optical Distribution Point (ODP), using passive splitter 1: 8 type of wall. Optical Distribution Cabinet (ODC) 1 unit to serve all the region in UR with a capacity of 24 core, using ODC 144 type. Calculation of the sample data taken, showing the speed of each customer in the Engineering Faculty using FttH is approximately 3 Mbps. Link Budget Calculations indicate that power received by each faculty on average $\mathbf{- 2 3 . 1 7}$ $\mathrm{dB}$, it can be concluded FttH network design is feasible and appropriate ethical standards that have been determined shall not exceed $-28 \mathrm{~dB}$. Attenuation of each faculty obtained the average value of $\mathbf{- 2 1 . 1 7} \mathrm{dB}$.
\end{abstract}

Keywords: FttH, link budget, network performance, Universitas Riau.

\section{INTRODUCTION}

University of Riau (UR) is one of the campus that has a very wide area reaching an area of approximately 700 hectares. UR has three separate campuses in several locations, namely Rumbai, Gobah, and Panam. On the campus of Rumbai, there is a Department of Sport Coaching while Gobah campus has Faculty of Law, Faculty of Medicine and Faculty of Nursing, while in Panam Campus there are 7 Faculties, Faculty of Economic, Faculty of Social and Political Sciences, Faculty of Agriculture, Faculty of Fisheries, Faculty of Engineering, Faculty of Teacher Training and Science Education, Faculty of Mathematics and
Natural Sciences. In addition there are also Rectorate Building, Library, and Computer Center. According to the data in 2016, UR has 92 Study Programs with a total of 27,708 students.

In order to connect three different campuses and cater to the needs of great students for communication and information, the University of Riau already has a local network of copper access and only connected with fiber optics in a number of places. However, the development and increasing need for data services in Riau University can not support by the current network conditions that still use the Local Copper Access Network. It have been inadequate for use in academic and administrative activities that almost entirely based on data and internet networks. System failures due to unreliable network conditions often occur in critical moments such as the student's Student Study Card (KRS) filling, student input time, new student enrollment, or when filling in the Lecturer Performance Index (IKD) performed online. This will be a more serious problem when system failure occurs during assessment process of accreditation of study program by BAN PT assessor at University of Riau. Some aspects of the assessment in the accreditation of study programs involving data and internet networks include the internet speed provided by the campus per-student, the existence of internet-based learning systems such as Learning Management System (LMS), Digital Library and access information that can be obtained through the academic community internet network on campus.

The need for broadband services is increasingly urgent. The fundamental difference is that Jarlok uses the main components of copper cable, while Jarlokaf uses the main components of fiber optic cable. In case the bandwidht of local local fiber access network (Jarlokaf) is superior to Jarlokat, so with this jarlokaf will be able to answer the challenge of Bandwidht explosion or Bandwidht Explosion. 
It is therefore necessary to plan and design for network replacement from copper access to fiber access as a whole. Local network fiber access has advantages of all aspects such as providing broadband services, greater bandwidth with a very fast transfer speed can even be used for long term.

One of the fiber access technologies currently widely used is Fiber To The Home (FTTH) technology. This technology uses a broadband Internet connection with fiber optic cable for personal or home-based and corporate users. As is well known, optical-based systems can deliver a variety of digital information, such as voice, video, data, and more effectively. When compared with copper cables that can carry data up to $1.5 \mathrm{Mbps}$ for short range (less than $2.5 \mathrm{~km}$ ), fiber optic cable can transport data up to $2.5 \mathrm{Gbps}$ for longer distances $(200 \mathrm{~km})$ means with a distance of 80 times longer, the fiber optic cable is capable of transporting data over 1,500 times the ability of copper cables [1]. Assessing the many advantages provided by fiber optic technology, the concept of FTTH is very suitable to be applied on the campus of the University of Riau.

By having a reliable information and telecommunication network, it is expected to support and accelerate the achievement of the vision of Universitas Riau in 2020 that is to become Research University as a center of maintenance, invention and development of science and technology and art.

The reliability of information and telecommunication networks is now a very important and urgent need for the University of Riau in order to support the achievement of the vision as a research university in 2020. The problem of system failure that often occur in data and internet network in UR one of them is because of the condition the inadequate physical copper cable network is used to carry high speed information. For that need to plan a new network as a replacement for the old network, the fiber optic network that supports high speed information transfer.

To design FTTH network at Riau Panam University, this research is limited to:

1. This research will make the design of Fiber To The Home (FTTH) which can be implemented in campus of Panam Universitas Riau

2. Search for the Sentral Telephone Otomat point (STO) which is closest to UR campus and the installation of Optical Distribution Cabinet (ODC)

3. Survey Planning design emphasized in accordance with the plan and service requirements contained in each faculty in Panam Campus.

This research aims to produce FTTH broadband network design planning that can be applied on campus of UR panam, to support multimedia / triple play service. It is expected that through this network planning can become the guideline for the application of new network of full fiber so that become solution to system failure on internet network and data that often happened in campus environment of Panam, Universitas Riau.

The general term comes from the generalization of several fiber dispersion configurations (FTTN, FTTC, FTTB, FTTH) [2]. All started with FTT but distinguished by the last letter, FTTX system has at least 2 (two) opto-electronic devices that are 1 (one) opto-electronic device on the central side and 1 (one) device on the customer side hereinafter called Optical Conversion Point (TKO). The difference of TKO location caused the application mode or FTTX architecture to be different. That is the author's discussion this time is FTTH (fiber to the home).

\section{As for some of the advantages of FTTH include [3]:}

1. FTTH provides customers with a wide range of communications and entertainment services, as well as faster activation of new services.

2. Direct FO cable deployment to each user will provide the maximum amount of bandwidth for service requests in the future. FTTH offers multiplay services ie data, voice, and video.

3. FTTH has a flexible network architecture design that can be used to accommodate future innovations.

4. Supporting the development and improvement of future networks.

5. Minimally spread of possible disruption, thus strengthening revenue from network owners and beneficial to FTTH customers.

6. Form a successful business, as it provides a balance between capital expenditure (CAPEX) and operating costs (OPEX).

\section{RESEARCH METHODOLOGY}

The method used in this study is to collect data from previous researchers for further analysis of the position of placement of the appropriate FTTH device in each faculty becomes the object of research.

The research objectives will be achieved through several process activities with the intention:

1. Conduct a survey of current network conditions (existing) in the seven faculties in the campus of Panam University of Riau and the needs of each faculty.

2. Planning and designing Fiber To The Home (FTTH) network design for application in seven campus faculty of Panam, UR. Activity is done by calculating network component requirement that is adjusted to the number of building to be served.

3. Conduct design analysis and FTTH link budget calculations.

4. Summing up all activities including design, analysis and calculation of FTHH network for campus needs of Panam, University of Riau.

\section{A. Research Steps}

The first step that needs to be done is to conduct a field survey that is collecting data of every faculty in Riau University such as: number of building, room, laboratory and number of student / i each faculty, after all data is complete then analyzed for proper room placement for FTTH devices as needed and in accordance with the calculation of the link budget obtained and the number of students who will be obtained how much the average speed of each student obtained, then done FTTH network design.

\section{Architecture and Topology FttH (Fiber to the Home).}

The Optical Conversion Point (TKO) is located inside the customer's home, the customer terminal is connected to the 
TKO through an indoor copper cable or IKR up to a few dozen meters, FTTH can be analogized as a terminal box replacement. This technological development is inseparable from the progress of fiber optic technology replaces conventional cabling and is also driven by the desire to acquire services known as Triple Play Services, which is a service of fast internet access, voice (telephone network, PSTN) and video (Cable TV) in a single infrastructure on a subscriber unit. Figure 1 shows the FTTx network topology.

Elements and FTTH Networks

In general, FTTH networks can be divided into 4 segments of cable in addition to active devices such as OLT and ONT, as follows [5]:

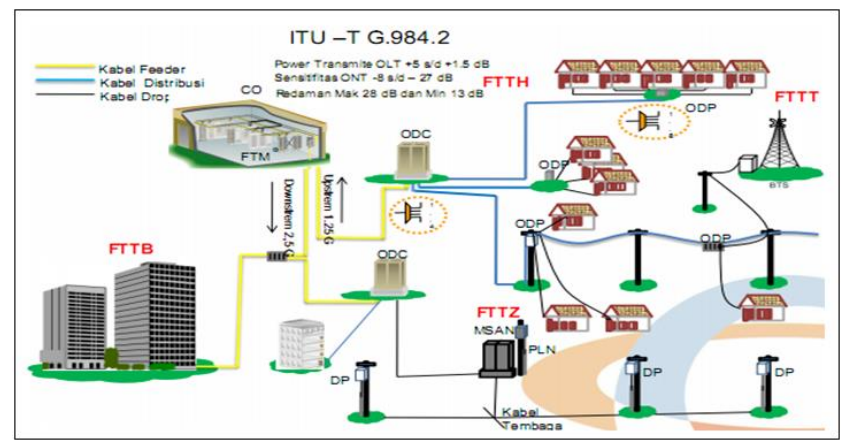

Figure 1: FTTx network topology (ITU-T G.984.2) [4]

FTTH network configuration is like picture 2 below:

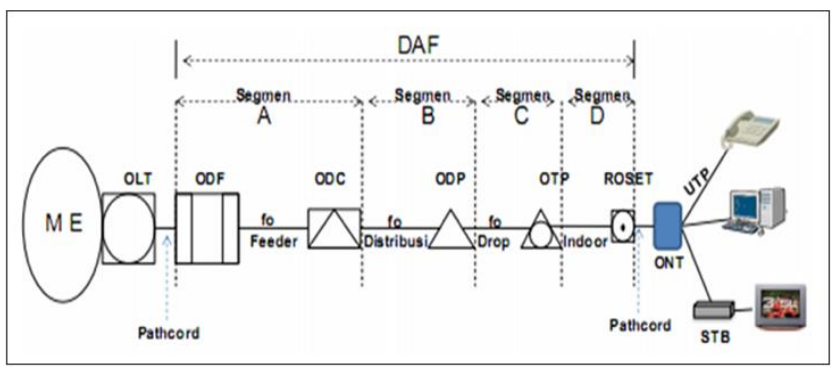

Figure 2: FTTH network architecture [4]

\section{Active Optical Line Terminal (OLT) Device}

Optical Line Terminal (OLT) is a device that serves as an end point of a passive optical network service. This device has two main functions, including:

- Convert between electrical signals and optical signals on passive optical networks.

- Coordinate multiplexing on other devices at the end of the network. Figure 3 is an example of an active OLT Device in an Indoor room.

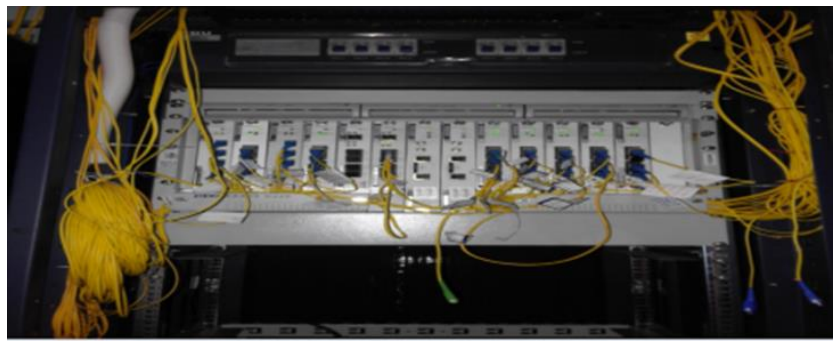

Figure 3: Optical Line Terminal

\section{ODC (Optical Distribution Cabinet)}

ODC is a passive device that is installed outside the STO can be in the field (Outdoor) and also biased inside the room / in the MDF HRB (Indoor) Building, See Figure 4 is an ODC example outside the room, ODC has the following functions:

- As the end point of the feeder cable and the base of the distribution cable

- As the cable distribution point from the large capacity (feeder) becomes some wires with even smaller capacity (distribution) for flexibility.

- Place Spliter.

- Place of connection.

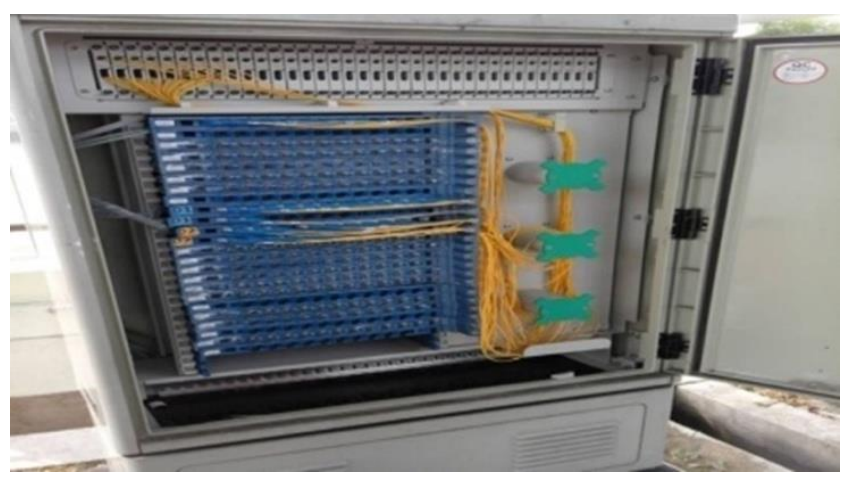

Figure 4: Optical Distribution Cabinet

\section{Optical Distribustion Point (ODP)}

ODP is also a passive device that is installed outside STO in the field and can also be indoors within the HRB building, which has the following functions:

- As the termination point of the distribution cable and the starting point of the starting / base of the drop / dock cable.

- As distribution distribution wiring points into multiple channel droppers (drop cables).

- Place Spliter .

- Place of connection. So this ODP must be equipped with space for splicing, spliter space and earth system. Look at Figure 5 for example some types of ODP 


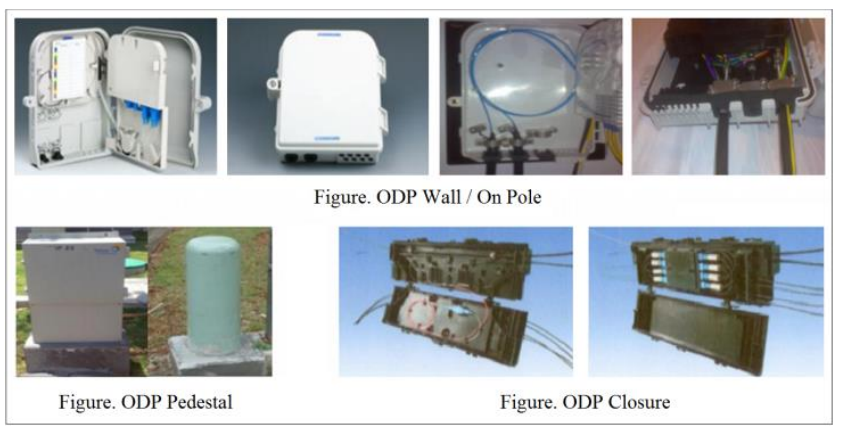

Figure 5: Types of ODP

\section{Optical Network Terminal (ONT)}

Optical Network Terminal is an active device (OptoEcektik) installed on the customer side, where ONU / ONT has the following functions:

- Changing Optical signals into Electrical Signals.

- As a demultiplex tool

Output from ONU / ONT is service

1. Telephoni (Voice)

2. Data and Internet.

3. Use TV

\section{Link Power Budget}

Link budget is a calculation of the actual situation that must be done in the FTTH application. In this calculation between optic and noise. This factor is very important to be calculated so that fiber optic network is completely complied with standard specification as recommended from ITU and IEEE. Fiber optic network performance is determined by the network transmission parameters of received signal power (Pr).

\section{Received signal power (Pr)}

Calculation of received signal power can be shown in the following equation [3]:

$\operatorname{Pr}=$ Pt-Lctotal -Lstotal - Lftotal - M

Where,

$\operatorname{Pr}=$ received signal power $(\mathrm{dBm})$

$\mathrm{Pt}=$ optical power emitted from the light source $(\mathrm{dBm})$

Lctotal $=$ Loss incurred on connector $(\mathrm{dB})$, can be formulated:

Lctotal $=$ Loss on connector $(\mathrm{dB})=\mathrm{Nc} x \mathrm{Lc}$

Lstotal $=$ Loss incurred in permanent connection / splice $(\mathrm{dB})$, can be formulated:

Lstotal $=$ Loss on splice $(\mathrm{dB})=\mathrm{Ns} x \mathrm{Ls}$

$\mathrm{Lf}_{\text {total }}=$ Loss incurred on Fiber Optics $(\mathrm{dB})$, can be formulated:

Lftotal $=$ Loss on Fiber Optics $(\mathrm{dB})=\mathrm{L} \times \alpha$

with:
$\mathrm{L}$ (channel length in $\mathrm{Km}$ )
$\alpha$ (damping fiber in $\mathrm{dB} / \mathrm{km}$ )
$M=$ Loss margin system of $6 \mathrm{~dB}$

\section{RESUlts AND DisCUSSION}

Link budget calculations to determine the permitted total attenuation limit between transmitter output power and receiver sensitivity. This calculation is based on ITU-T G.984 standardization and also GPON optical fiber network from OLT and ONU/ONT is $28 \mathrm{~dB}$ (GPON). To anticipate operational requirements (FO network improvements), the FTTH design with a maximum damping of $25 \mathrm{~dB}$ or equivalent to the optical fiber length of OLT up to a maximum of $17 \mathrm{~km}$ as shown in Figure 6 below [1]:

For that we need to know the parameters of design performance of Local Network Access Fiber used are: Lf (Loss Fiber), Ls (Loss splice / Connection), Lc (Loss Conector), Lsp (Loss splitter on PON technology), Pr (signal power received), $\mathrm{M}$ (Loss margin), L (transmission distance).), The analysis was performed using the following Table of Characteristics [3]:

a. Loss fiber (Lf)

The calculation of link budget for each faculty can be seen in Table 2 below:

b. Loss splice / Ls

Given: The connection loss is $0.10 \mathrm{~dB} /$ piece (See Figure 8 ) using equation (3) as follows:

Lstotal $=$ Ns $x$ Ls $=3 \times 0.1 \mathrm{~dB}=0.3 \mathrm{~dB}$

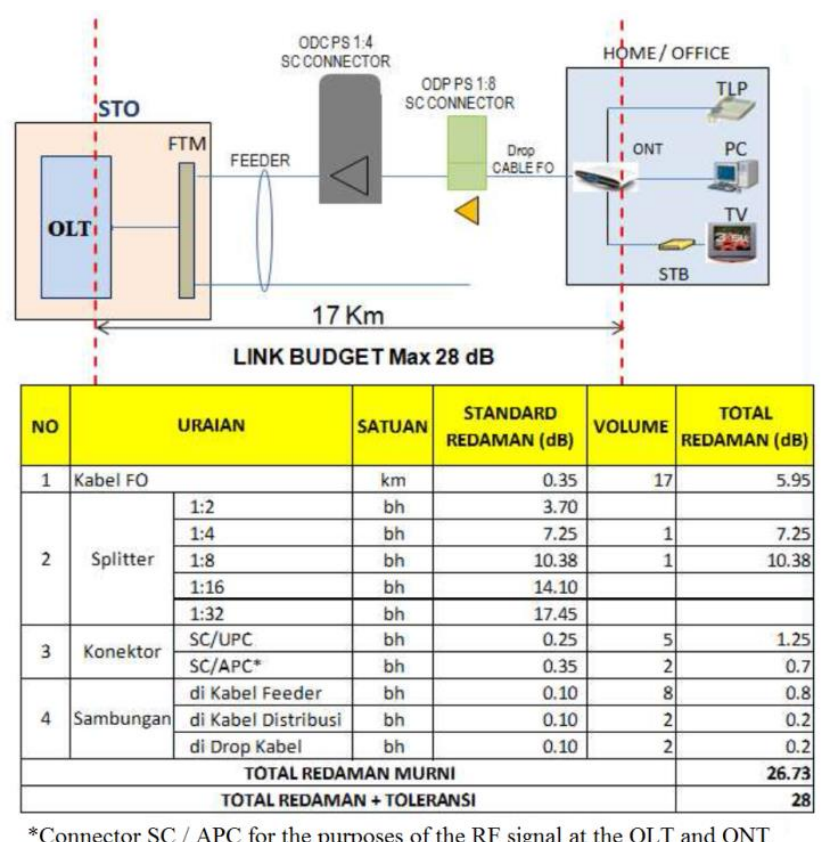

Figure 6: Link Budget Linking Standards [1]

Table 1: Link Parameters Link Specification [3]

\begin{tabular}{|l|l|l|l|}
\hline Link parameters & Symbol & Value & Unit \\
\hline
\end{tabular}




\begin{tabular}{|c|c|c|c|}
\hline Light source type & & ILD & \\
\hline Wavelength & $\Lambda$ & 1310 & $\mathrm{Nm}$ \\
\hline Output Power & $\mathrm{Pt}$ & -5 & $\mathrm{dBm}$ \\
\hline Type of light detector & & $\mathrm{PIN}$ & \\
\hline Dark Current & Idark & 2 & $\mathrm{nA}$ \\
\hline Responsifity & $\mathrm{R}$ & 0,85 & $\mathrm{~A} / \mathrm{W}$ \\
\hline Bandwidht & $\mathrm{B}$ & 0,5 & $\mathrm{GHz}$ \\
\hline Equivalent resistance & $\mathrm{Rload}$ & 50 & $\Omega$ \\
\hline Types of Optical fiber cables & & $\mathrm{SM}-\mathrm{SI}$ & \\
\hline $\begin{array}{c}\text { Core Diameter } \\
\text { Optical fiber bandwidth }\end{array}$ & $\mathrm{Dcore}$ & 9 & $\mu \mathrm{m}$ \\
\hline $\begin{array}{c}\text { Fiber optic cable attenuation } \\
\text { coefficient }\end{array}$ & $\mathrm{A}_{\mathrm{f}}$ & 0,40 & $\mathrm{~dB} / \mathrm{Km}$ \\
\hline $\begin{array}{c}\text { Numerical Aperture } \\
\text { NA }\end{array}$ & 0,20 & \\
\hline
\end{tabular}

Loss / optical fiber attenuation can be determined by (2.4) as follows:

Given: $\mathrm{L}=(\mathrm{STO}-\mathrm{ODC})+(\mathrm{ODC}+\mathrm{ODP})+(\mathrm{ODP}+$ ONT)

$$
\begin{gathered}
=(8.7 \mathrm{Km}+0.6 \mathrm{Km}+0.15 \mathrm{Km}) \\
=9.45 \mathrm{Km}
\end{gathered}
$$

Lftot $=\mathrm{L} \times \alpha \mathrm{f}=9.45 \mathrm{Km} \times 0.40 \mathrm{~dB} / \mathrm{km}=3.78 \mathrm{~dB}$

Table 2: Budget Link of each Faculty

\begin{tabular}{|c|c|c|c|c|c|c|}
\hline FAK. & FT & FMIPA & FE & FISIP & FKIP & FPERI \\
\hline $\begin{array}{c}\text { STO- } \\
\text { ODC } \\
(\mathrm{KM})\end{array}$ & 8.7 & 8.7 & 8.7 & 8.7 & 8.7 & 8.7 \\
\hline $\begin{array}{c}\text { ODC- } \\
\text { ODP } \\
(\mathrm{KM})\end{array}$ & 0.45 & 0.8 & 0.7 & 0.45 & 0.3 & 0.26 \\
\hline $\begin{array}{c}\text { ODP- } \\
\text { ONT } \\
(\mathrm{KM})\end{array}$ & 0.15 & 0.15 & 0.15 & 0.15 & 0.15 & 0.15 \\
\hline $\mathrm{L}(\mathrm{KM})$ & 9.3 & 9.65 & 9.55 & 9.3 & 9.15 & 9.11 \\
\hline $\begin{array}{c}\alpha \mathrm{f} \\
(\mathrm{dB} / \mathrm{km})\end{array}$ & 0.4 & 0.4 & 0.4 & 0.4 & 0.4 & 0.4 \\
\hline $\mathrm{Lf}_{\text {tot }}(\mathrm{dB})$ & 3.72 & 3.86 & 3.82 & 3.72 & 3.66 & 3.644 \\
\hline $\mathrm{Pt}_{(\mathrm{dB})}$ & -5 & -5 & -5 & -5 & -5 & -5 \\
\hline $\mathrm{Ls}_{\text {total }(\mathrm{dB})}$ & 0.3 & 0.3 & 0.3 & 0.3 & 0.3 & 0.3 \\
\hline $\mathrm{Lc}_{\text {total }(\mathrm{dB})}$ & 0.75 & 0.75 & 0.75 & 0.75 & 0.75 & 0.75 \\
\hline
\end{tabular}

\section{REFERENCES}

[1] Idham, A., M. Tadarus \& Wildan, "Analysis and Design of FTTH Network (Fiber to The Home) with GPON Technology at PT Telkom Indonesia tbk, University of Indonesia, 2013.

[2] Agus, T, H, .P, Revelation, "Planning and Design Survey of FTTH in STO Karangmulya Area Using Google Earth In Telkom Work Area Access Cirebon, journal planning_dandesign_survey_ftth_di_wi.pdf", 2014.

[3] Angga J. "Planning of Metro FTTH Network Design at Universitas Indonesia, Journal digital_20311709-S43360-Design planning.pdf", 2012.

\begin{tabular}{|c|c|c|c|c|c|c|}
\hline Lsp (dB) & 10.38 & 10.38 & $\begin{array}{c}10.3 \\
8\end{array}$ & 10.38 & 10.38 & 10.38 \\
\hline $\mathrm{M}(\mathrm{dB})$ & 3 & 3 & 3 & 3 & 3 & 3 \\
\hline $\operatorname{Pr}(\mathrm{dBm})$ & -23.15 & -23.29 & $\begin{array}{c}23.2 \\
5\end{array}$ & -23.15 & -23.09 & -23.074 \\
\hline
\end{tabular}

c. Loss connector (Lc)

Given: Loss Conector is $0.25 \mathrm{~dB}$ (See 8) using equation (2) as follows:

Lctotal $=\mathrm{Nc} \times \mathrm{Lc}=3 \times 0.25 \mathrm{~dB}=0.75 \mathrm{~dB}$

d. Loss Splitter (Lsp)

Given: Splitter 1: $8=10.38 \mathrm{~dB}$ (See Figure 8)

e. Loss margin (M)

Known $=$ Margin $=3 \mathrm{~dB}$

f. Received signal power (Pr)

The received power in the receiver can be determined by using equation (1) as follows:

$$
\begin{aligned}
\operatorname{Pr} & =\text { Pt-Lctotal -Lstotal }- \text { Lftotal }- \text { Lsp }-\mathrm{M} \\
& =-5 \mathrm{~dB}-3.78 \mathrm{~dB}-0.3 \mathrm{~dB}-0.75 \mathrm{~dB}-10.38 \mathrm{~dB}-3 \\
& =-23.21 \mathrm{~dB}
\end{aligned}
$$

\section{CONCLUSION}

The result of Broadband Fiber To The Home network design in Riau University requires 209 units of Optical Network Terminal, with details of FT 40 units, FMIPA 33 units, FE 19 units, 29 units of FISIP, 33 FKIP, FAPERI 27 and FAPERTA 28 Fruits tailored to the needs of each service faculty, laboratory, and building / room. Optical Distribution Point device used amounted to 34 units using Passive Spliter 1: 8, ODP type wall / pol can be attached on the wall or between two poles. Optical Distribution Cabinet 1 fruit to serve all areas of Riau University with Type ODC 144 capacity 24 cores. The speed of each Customer in the Faculty of Engineering by using FTTH designed from the calculation results approaching $3 \mathrm{Mbps}$. The received power of each faculty averaged $-23.17 \mathrm{~dB}$, so the planning of FTTH in katakana feasible and well according to predetermined standard that does not exceed $-28 \mathrm{~dB}$. Large attenuation of $\begin{array}{llll}\text { each faculty average } & -21,17 & \mathrm{~dB}\end{array}$

[4] PT Telekomunikasi Indonesia tbk, "FTTH Design Document: In Bandung Indonesia", 2013

[5] PT Telekomunikasi Indonesia Tbk, "Fiber To The Home Networking Guide: Bandung Indonesia", 2013. 